\title{
Effect of Process Parameters for Resistance Spot Welding Process using Taguchi Method for 2.0mm Sheet Thickness
}

\author{
Makwana Brijesh V. ${ }^{1}$, Shah Jay $D^{2}$, Bhatt Jayant A. ${ }^{3}$ \\ ${ }^{1}$ Asst. Professor, Mechanical Engg. Department, Parul University, Faculty of Engineering and Technology, Vadodara \\ ${ }^{2}$ U G Student, Mechanical Engg. Department, Parul Institute of Engineering and Technology, Vadodara \\ ${ }^{2} \mathrm{U}$ G Student, Mechanical Engg. Department, Parul Institute of Engineering and Technology, Vadodara
}

\begin{abstract}
Resistance spot welding is commonly used in the automotive industry, because it has the advantage which is high speed, high-production assembly lines and suitability for automation. By using the varying process parameters for Resistance Spot Welding Process to affect the weld quality and weld strength. From the experimental setup work piece is used for Spot welded of $2.0 \mathrm{~mm}$ sheet thickness for Austenitic Stainless Steel material and also to Taguchi Method, ANOVA analysis and Macro Examination to find the optimum results.
\end{abstract}

Keywords: Resistance Spot Welding Machine, Austenitic SS304, Taguchi Method

\section{Introduction}

Resistance spot welding (RSW) is a process in which metal surfaces are joined in one or more spots by resistance to the flow of electric current through work pieces that are held together under force by electrodes. For the combination of heat, pressure and time to make a spot weld of the different materials. The process is used for joining sheet materials and uses shaped copper alloy electrodes to apply pressure and convey the electrical current through the work pieces. In resistance welding, the heat are required to create the coherence is generated by applying an electric current through the stack- up of sheets between the electrodes. So, the formation of a welded joint, including the nugget diameter and the heat- affected zone (HAZ), are definitely depends on the electrical and thermal properties of the sheets and coating materials. The general expression of heat generated in an electric circuit can be expressed as,

$$
\mathrm{Q}=\mathrm{I}^{2} \mathrm{RT}
$$

Where, $\mathrm{Q}=$ Heat (Joule), $\mathrm{I}=$ Current (Ampere), $\mathrm{R}=$ Electrical resistance of the circuit (ohm, $\Omega$ ) and $\mathrm{T}=$ Time (second).

Figure-1 represents the general working of resistance spot welding. Two metal sheets are welded together. Electrode force is applied to hold the sheets tightly together, and electrical current flows through the electrodes and the material. The resistance of the material being welded is much higher than the resistance of the electrodes. Thus, enough heat is generated to melt the metal. The pressure on the electrodes forces the molten spots in the two pieces of metal to unite, forming the final spot (nugget).

Basically, RSW is a cyclic process at various stages. The first cycle is the squeeze time, where pressure from the electrode force is applied to the workpieces. The second cycle is weld time, this process where the current is on and the welding current is applied in the metal sheets to melt the sheet metal for the welding process. Then, post heat time, the current delay at the low level. The fourth cycle is cool time. This cycle allow the melt nugget diameter to solidify before the releasing the welded parts and lastly the off time cycle, the electrode force applied on the sheets metal is released the welding process is done. [12]

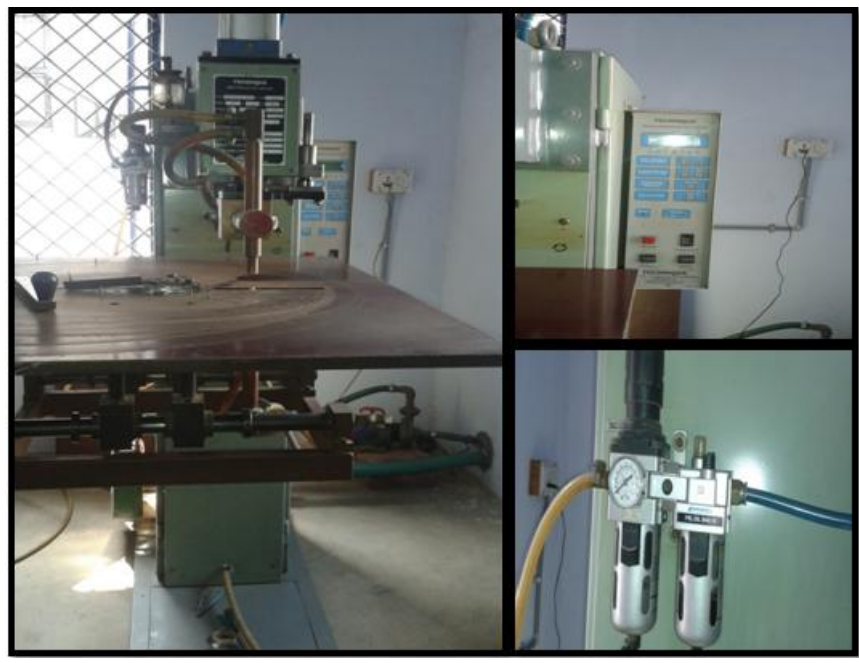

Figure 1: General setup of Resistance Spot Welding Process

\section{Literature Survey}

Dursun Ozyurek (2007) [1] studied an effect of weld current and weld atmosphere on the resistance spot welding process. He used material for the experiments as an Austenitic Stainless Steel 304 because of their superior mechanical and corrosion properties. From the experimental setup, the welding current is chose at three different levels whereas, weld time, hold time and electrode pressure are constant. For the results of experiment to shows that, current is most effective parameters than others and also to optimum 


\section{International Journal of Science and Research (IJSR) \\ ISSN (Online): 2319-7064}

Index Copernicus Value (2015): 78.96 | Impact Factor (2015): 6.391

welding parameter for maximum joint strength at 9kA. Hessamoddin Moshayedi and Iradj Sattari-far (2011) [2] developed a model of electro-thermo-mechanical finite element to study the effect of welding time and current intensity on nugget size for resistance spot welding process using Austenitic SS304L steel sheets. Form the experimental results to shows that compare the diameter \& thickness of computed weld nugget size, and also to FE model predicted to weld nugget growth and nugget size. Nachimani Charde and Aravinthan Arumugam (2011) [3] this paper focuses on the effect of parametric changes for dissimilar joints using 304 austenitic stainless steel and carbon steel with two different thicknesses. For the experimental setup the welding current and welding time are varying different levels while electrode force and electrode tips size are constant. From the results to find the tensile test, hardness test and metallurgical test for spot weld nugget growth of both the thickness and to find optimum parametric setup for $1 \mathrm{~mm} \& 2 \mathrm{~mm}$. Nachimani Charde (2012) [4] has been analysis and effect of weld growth for spot welding process of Mild steel \& Stainless steel for $1 \mathrm{~mm} \& 2 \mathrm{~mm}$ sheet thickness. From the experimental work at varying process parameters like welding current, weld time, electrode pressure \& tip size of electrode used. For the results, the mechanical tensile test \& hardness test to carried out to characterize the formation of weld nugget growth for different thickness while Macro examination of weld nugget shows the differences in weld growth in both thicknesses. R.J.Bowers, et al (1990) [5] has investigated of electrode geometry on current distribution by both mathematical modeling and experimental testing. From the experimental setup to developed a mathematical model to evaluate current distribution and also to find the electrode life. For the results to shows that on both an angle of 90 degree to provide more uniform current distribution and affect wear and life of electrode on local current distribution. A. Aravinthan and C. Nachimani (2011) [6] have investigated to analyze only the effects of nugget growth on mild steel, stainless steel, and mixed steels with respect to the variation of current and weld time whereas electrode force and electrode tips kept constant throughout the experiments. From the experiments to find the tensile, hardness and metallurgical testing to characterize the formation of weld nuggets. The results to shows that hardness of the welded zone is greater than the unwelded zone and tensile test shows significant relationship between differing current increments and sufficient weld time to attain a proper weldment. A. K. Pandey, et al (2013) [7] have been represents the optimization of various process parameters for resistance spot welding process using Taguchi Method. From the experiments to investigate of varying process parameters to effect of the quality characteristic using Taguchi Method. At last experimental result shows that, current is most effective machining parameters where the holding time and pressure are less. B.D.Gurav and S.D.Ambekar (2013) [8] studied on the optimization and the effect of the welding parameters on the tensile shear strength of the resistance spot welded joints for using CRCA (close rolled close annealing) steel sheets with $2 \mathrm{~mm}$ thickness. For using orthogonal array of Taguchi method, the signal-to-noise ratio, the analysis of variance (ANOVA) employed to find the optimal process parameters levels and to analyze the effect of these parameters on tensile shear strength values. Norasiah Muhammad and Yupiter Hp Manurung (2012) [9] have been investigates the development of weld zone in Resistance Spot Welding for $1.21 \mathrm{~mm}$ thick coated low carbon steel sheet. For the experimental to study the effect of factors weld current, weld time, electrode force and hold time on the development of weld zone. On the results define that all the selected factors expect hold time affected the radius of weld nugget and HAZ (Heat Affected Zone) significantly and optimized using the Central Composite Design by RSM.

From the above literature to find that Very few researchers have been used the Austenitic Stainless Steel304 material for $2.0 \mathrm{~mm}$ thickness for study on Resistance Spot Welding process. So now we will do experimental work with using SS304 material for $2.0 \mathrm{~mm}$ sheet thickness by Taguchi experimental design.

\section{Experimental Procedure}

In this research, we are selecting the $2.0 \mathrm{~mm}$ thick ASTM A240 standard Stainless Steel304 sheets used as the base metals. Stainless Steel 304 have good welding characteristics. Table $1 \&$ Table 2 represent the Mechanical Properties and Chemical Composition for SS304 material. Spot welding was performed using $15 \mathrm{kVA}$ AC pedestal type Resistance Spot Welding machine operating $50 \mathrm{~Hz}$. Welding was conducted using 45-deg truncated cone RWMA class 2 electrode with $7 \mathrm{~mm}$ face diameter. Welding machines with the following specifications: STW-15: Duty 50\% input capacity for $15 \mathrm{kVA}$, compressed air at $1.5 \mathrm{~kg} / \mathrm{cm} 2$ to 6.0 $\mathrm{kg} / \mathrm{cm} 2$ acting on the pneumatic cylinder provides electrode force. Transformer, Electrode and Arms \& Holders are water cooled and required to 101 itre $/ \mathrm{min}$.

Table 1 Mechanical Properties of SS304

\begin{tabular}{|c|c|c|c|c|}
\hline Property & $\begin{array}{c}\text { Ultimate tensile } \\
\text { Strength (MPa) }\end{array}$ & $\begin{array}{c}\text { Compressive } \\
\text { Strength (MPa) }\end{array}$ & $\begin{array}{c}\text { Elongation } \\
\text { min. (\%) }\end{array}$ & $\begin{array}{c}\text { Hardness } \\
\text { (HRB) }\end{array}$ \\
\hline Value & 520 to 720 & 200 & 45 & 95 \\
\hline
\end{tabular}

Table 2: Chemical Composition of SS304

\begin{tabular}{|c|c|}
\hline Elements & $\%$ Presents \\
\hline Carbon $(\mathrm{C})$ & $0.0-0.07$ \\
\hline Chromium $(\mathrm{Cr})$ & 18.50 \\
\hline Manganese $(\mathrm{Mn})$ & $0.0-2.00$ \\
\hline Silicon $(\mathrm{Si})$ & $0.0-1.0$ \\
\hline Phosphorus $(\mathrm{P})$ & $0.0-0.05$ \\
\hline Sulphur $(\mathrm{S})$ & $0.0-0.2$ \\
\hline Nickel $(\mathrm{Ni})$ & 8.30 \\
\hline Iron $(\mathrm{Fe})$ & -- \\
\hline
\end{tabular}

From the good welding characteristic, we select the SS304 material for the specimen dimension $100 \times 40 \times 2.0 \mathrm{~mm}$ as per the ASTM-A240 standards as shown in the Figure 2. From the literature survey we select the process parameters at different levels as shown in Table-3. 
International Journal of Science and Research (IJSR)

ISSN (Online): 2319-7064

Index Copernicus Value (2015): 78.96 Impact Factor (2015): 6.391

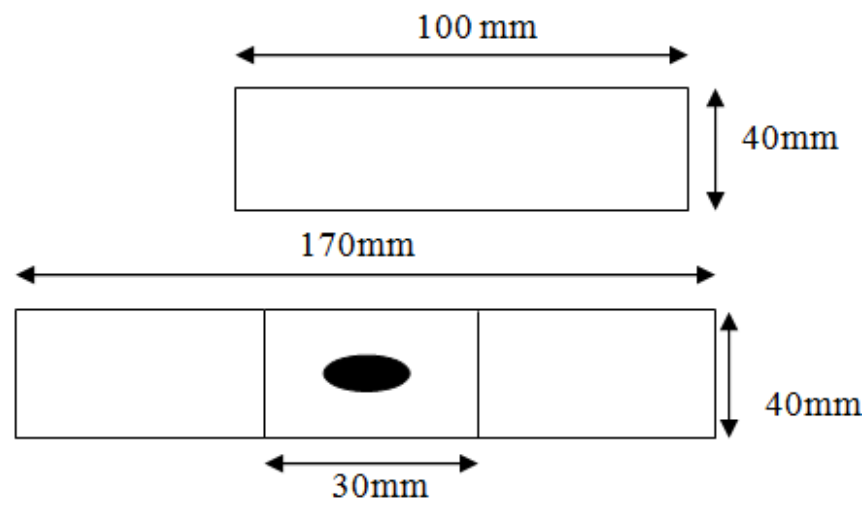

Figure 2: Standard Dimension of SS304 sheet for $2 \mathrm{~mm}$ thickness

Taguchi method is used to reduce the number to run for experimental work and find the optimum results very easily. It can be efficiently used for designing a system that operates consistently and optimally over a variety of conditions. It is most important in designing, formulating, developing \& analyzing new scientific studying and products. The common applications of Taguchi Method are in Analytical simulation, Development testing (In design and development), Process Development, problem solving in all areas of manufacturing and production [11].

Experimentation is the important step in the total analysis. Total 27 runs of experiments based on randomized OA were done. Pressure, Power, and Weld time are varied as per values for each level mentioned in Table-3. Three responses are taken for each setting. The experimental data is given in Table-4.

Table 3: Level of Experiment

\begin{tabular}{|c|c|c|c|c|}
\hline Factor & Column & Level 1 & Level 2 & Level 3 \\
\hline Pressure (Bar) & A & 2 & 2.5 & 3 \\
\hline Welding Power (\%) & B & 45 & 50 & 55 \\
\hline Weld time (cycle/sec) & C & 12 & 14 & 16 \\
\hline
\end{tabular}

Typically, there are three stages in RSW processes: in the first stage, the electrodes are brought together against the metal and pressure is applied before the current is turned on. Next stage, the current is turned on and is maintained a time (cycles) this is followed by the third stage, or hold time in which the current is turned off but the electrodes are still pressed on the weld joint.

Tensile shear test was used to explore mechanical properties of the joints. Mechanical test were performed of a cross head of 500rev/min with an Instron Universal Testing Machine
Table 4: L27 Orthogonal array (D.O.E)

Sr No. Pressure (bar) Power (\%) Weld Time (cycle/sec)

\begin{tabular}{|c|c|c|c|}
\hline 1 & 2 & 45 & 12 \\
\hline 2 & 2 & 45 & 14 \\
\hline 3 & 2 & 45 & 16 \\
\hline 4 & 2 & 50 & 12 \\
\hline 5 & 2 & 50 & 14 \\
\hline 6 & 2 & 50 & 16 \\
\hline 7 & 2 & 55 & 12 \\
\hline 8 & 2 & 55 & 14 \\
\hline 9 & 2 & 55 & 16 \\
\hline 10 & 2.5 & 45 & 12 \\
\hline 11 & 2.5 & 45 & 14 \\
\hline 12 & 2.5 & 45 & 16 \\
\hline 13 & 2.5 & 50 & 12 \\
\hline 14 & 2.5 & 50 & 14 \\
\hline 15 & 2.5 & 50 & 16 \\
\hline 16 & 2.5 & 55 & 12 \\
\hline 17 & 2.5 & 55 & 14 \\
\hline 18 & 2.5 & 55 & 16 \\
\hline 19 & 3 & 45 & 12 \\
\hline 20 & 3 & 45 & 14 \\
\hline 21 & 3 & 45 & 16 \\
\hline 22 & 3 & 50 & 12 \\
\hline 23 & 3 & 50 & 14 \\
\hline 24 & 3 & 50 & 16 \\
\hline 25 & 3 & 55 & 12 \\
\hline 26 & 3 & 55 & 14 \\
\hline 27 & 3 & 55 & 16 \\
\hline & & & \\
\hline
\end{tabular}

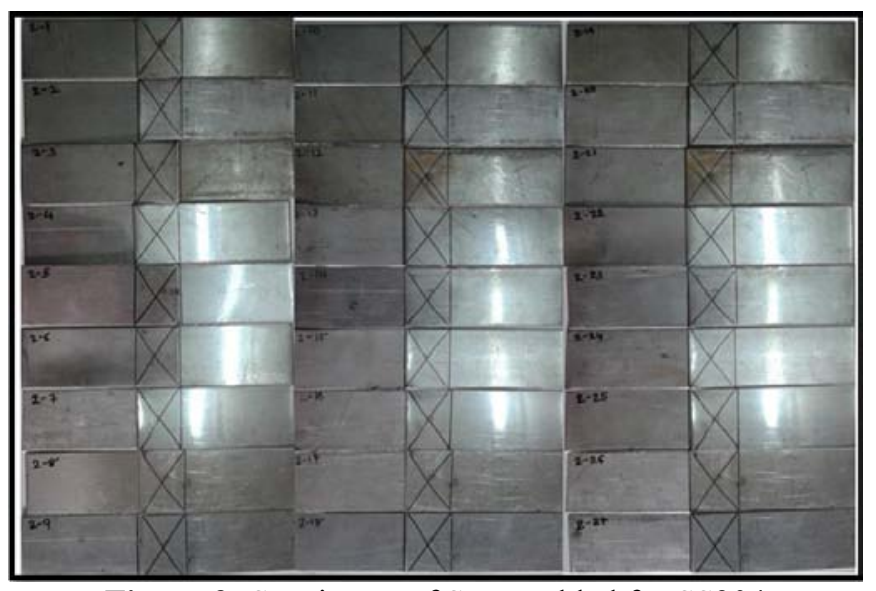

Figure 3: Specimens of Spot welded for SS304

\section{Analysis of Result and Discussions}

\section{Mechanical testing of SS304 welded workpieces}

Tensile testing is used to provide basic design information on the strength of materials and is an acceptance test for the specification of materials. In the welding process the specimen are welded through the orthogonal array design. The experiments are completed then after the tensile test operating of welded parts to find its strength. Universal Testing Machine is used to test the tensile test of welded materials and the result to be finding in form of Maximum load and Break load as shown in Table 5 


\section{International Journal of Science and Research (IJSR) \\ ISSN (Online): 2319-7064}

Index Copernicus Value (2015): 78.96 | Impact Factor (2015): 6.391

Table 5: Result table

\begin{tabular}{|c|c|c|c|c|c|c|c|}
\hline Sr No. & $\begin{array}{c}\text { Pressure } \\
(\text { bar })\end{array}$ & $\begin{array}{c}\text { Power } \\
(\%)\end{array}$ & $\begin{array}{c}\text { Weld Time } \\
(\text { Cycle/sec })\end{array}$ & $\begin{array}{c}\text { Max Load } \\
(N)\end{array}$ & $\begin{array}{c}\text { Break Load } \\
(N)\end{array}$ & $\begin{array}{c}\text { Nugget Dia. } \\
(\mathrm{mm})\end{array}$ & $\begin{array}{c}\text { Tensile Strength } \\
(\text { N/mm })\end{array}$ \\
\hline 1 & 2 & 45 & 12 & 3587.5 & 750 & 3.9 & 17519.43 \\
\hline 2 & 2 & 45 & 14 & 3485 & 660 & 3.8 & 15817.35 \\
\hline 3 & 2 & 45 & 16 & 3330 & 1045 & 4.0 & 10526.85 \\
\hline 4 & 2 & 50 & 12 & 5207.5 & 1472.5 & 4.3 & 11564.46 \\
\hline 5 & 2 & 50 & 14 & 4942.5 & 3610 & 4.4 & 17175.01 \\
\hline 6 & 2 & 50 & 16 & 4632.5 & 3457.5 & 4.4 & 15703.61 \\
\hline 7 & 2 & 55 & 12 & 4855 & 1167.5 & 4.7 & 20310.69 \\
\hline 8 & 2 & 55 & 14 & 6057.5 & 3880 & 4.6 & 12593.36 \\
\hline 9 & 2 & 55 & 16 & 6237.5 & 4625 & 4.9 & 9923.97 \\
\hline 10 & 2.5 & 45 & 12 & 4505 & 1575 & 4.5 & 7365.26 \\
\hline 11 & 2.5 & 45 & 14 & 4005 & 1880 & 4.8 & 13536.54 \\
\hline 12 & 2.5 & 45 & 16 & 3925 & 1120 & 4.3 & 12227.74 \\
\hline 13 & 2.5 & 50 & 12 & 5562.5 & 2702.5 & 4.9 & 14799.40 \\
\hline 14 & 2.5 & 50 & 14 & 4497.5 & 2062.5 & 4.8 & 7036.74 \\
\hline 15 & 2.5 & 50 & 16 & 3550 & 1450 & 4.8 & 6358.5 \\
\hline 16 & 2.5 & 55 & 12 & 5875 & 4655 & 4.6 & 8368.49 \\
\hline 17 & 2.5 & 55 & 14 & 5240 & 875 & 3.8 & 15437.02 \\
\hline 18 & 2.5 & 55 & 16 & 5417.5 & 2067.5 & 3.9 & 15085.54 \\
\hline 19 & 3 & 45 & 12 & 4390 & 1677.5 & 4.5 & 6358.5 \\
\hline 20 & 3 & 45 & 14 & 4240 & 1245 & 4.4 & 10906.00 \\
\hline 21 & 3 & 45 & 16 & 3217.5 & 855 & 4.9 & 6548.66 \\
\hline 22 & 3 & 50 & 12 & 5280 & 3292.5 & 4.3 & 7073.36 \\
\hline 23 & 3 & 50 & 14 & 4382.5 & 1042.5 & 4.7 & 8273.70 \\
\hline 24 & 3 & 50 & 16 & 4587.5 & 695 & 4.5 & 5325.24 \\
\hline 25 & 3 & 55 & 12 & 6347.5 & 4177.5 & 4.2 & 10805.91 \\
\hline 26 & 3 & 55 & 14 & 6140 & 4317.5 & 4.0 & 8454.45 \\
\hline 27 & 3 & 55 & 16 & 6755 & 3677 & 4.2 & 15009.59 \\
\hline
\end{tabular}

Formula for strength $=$ Breaking Load/ Shearing

Area $=\mathrm{P} / 2 \pi \mathrm{Dt}$

Where $\mathrm{D}=$ Nugget diameter,

$\mathrm{t}=$ Thickness of specimen,

$\mathrm{P}=$ Breaking Load

From the Results to shows that higher amount of pressure and weld time applying the material to given higher strength. So the given Result Table 5 test Specimen-7 for high Tensile strength while Specimen-24 having low Tensile Strength.

\section{Macro/Micro examination of SS304 material:}

Macroscopic examination techniques are frequently employed in routine quality control, in failure analysis, and in research studies. In macroscopic examination, material has been cut into center of the weld area, and the optical microscopic is used to clearly shown the structure and diameter of nugget for spot weld. From the Figure-5 shows that the microscopic examine of $2 \mathrm{~mm}$ sheet thickness and identify the zones of the weld area easily.

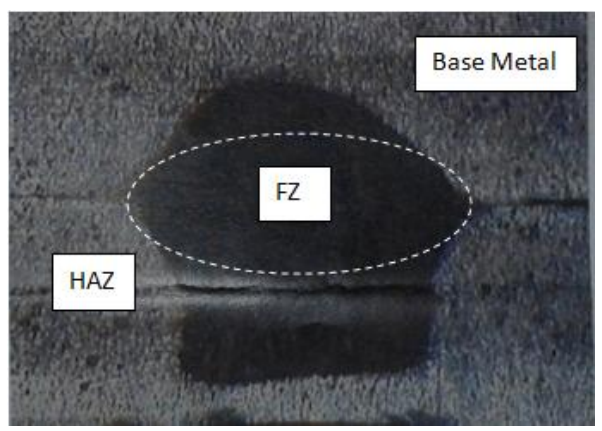

Figure 4: Microscopic examination of SS304 material

\section{Effect of process parameters on weld area:}

Welding parameters can significantly affect the weld nugget growth and fusion zone in microstructure. The weld strength is higher, when the pressure is 2 bar, power is $55 \%$ and, weld time is 12 cycle/sec. while it is lower, when pressure is 3 bar; power is $50 \%$ and, weld time is 16 cycle/sec. So, when pressure is increasing with respect to power and weld time is decreases to given lower strength of weld. The nugget area of weld is increases when the power is increased and weld time is maintained. Pressure is also effective parameter to tensile strength of weld area.

\section{Analysis of variance (ANOVA) Terms \& Notations:}

$\mathrm{n}=$ numbers of trails $\mathrm{T}=$ Total of results

C.F. $=$ correction factor $\mathrm{e}=$ Error $\mathrm{S}=$ Sum of squares

$\mathrm{F}=$ variance ratio $\quad \mathrm{S}^{\mathrm{c}}=$ Pure sum of squares

$\mathrm{f}=$ Degree of freedom $\quad \mathrm{V}=$ Mean squares (variance)

$\sum \mathrm{yi}=$ sum of all output values $\quad \mathrm{P}=$ Percent contribution

Table 6 Response Table for Signal to Noise Ratio (Larger is better)

\begin{tabular}{|c|c|c|c|}
\hline Level & A & B & C \\
\hline $\mathbf{1}$ & 67.46 & 65.38 & 68.79 \\
\hline $\mathbf{2}$ & 67.79 & 68.28 & 68.17 \\
\hline $\mathbf{3}$ & 67.90 & 69.48 & 66.18 \\
\hline Delta & 0.44 & 4.10 & 2.62 \\
\hline Rank & 3 & 1 & 2 \\
\hline
\end{tabular}

Analysis of Variance tables to display for the effect of parameter on weld strength. Minitab software is used to significant parameters can be easily identified and also find the rank order. Rank order as per the significance level is that 


\section{International Journal of Science and Research (IJSR) \\ ISSN (Online): 2319-7064}

Index Copernicus Value (2015): 78.96 Impact Factor (2015): 6.391

Weld time, Power and Pressure. The requirement of the optimum level can be decide by $\mathrm{SN}$ ratio plot. Here, the maximum $\%$ contribution in all three parameter is of pressure and weld time, whereas power is less.

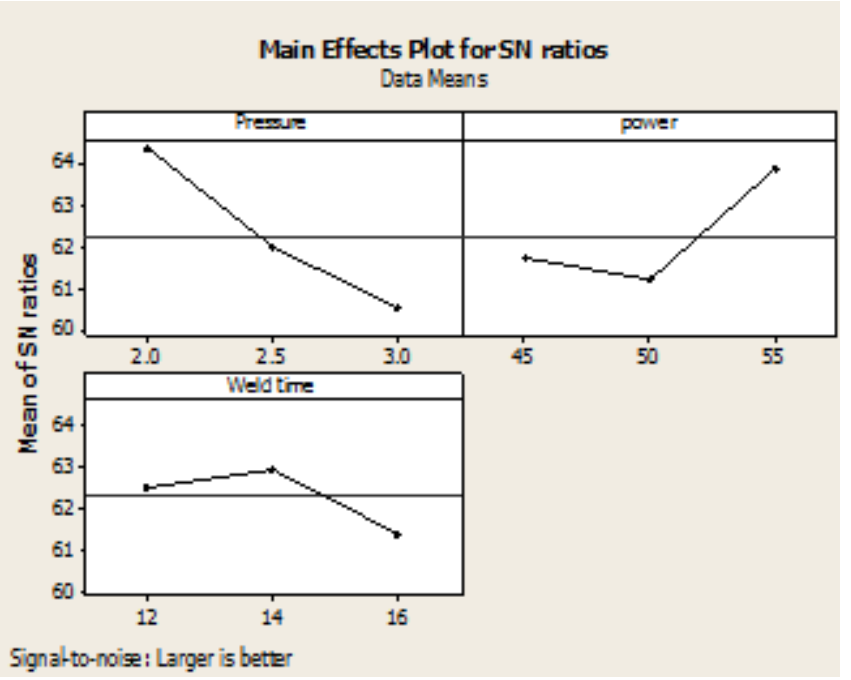

Figure 5: Main effect for $\mathrm{S} / \mathrm{N}$ ratios of SS304 material

From the Figure-5 shows the optimum combination of process parameter, where pressure is 2 bar, power $55 \%$ and, weld time 14 cycle/sec.

\section{Conclusion}

This project contains the investigation and optimization of welding parameters during spot welded SS 304 on steel sheet. The level of importance of the welding parameters during tensile test is determined by ANOVA method. This gives the results of various highly effective parameters as well as comparison between them, whereas Pressure was observed less effective factor. Optimization has been done on the parameters for the maximum tensile shear strength by using the analysis of signal-to-noise $(\mathrm{S} / \mathrm{N})$ ratio. The confirmation test results as discussed below,

- Resistance spot welding process is comparatively fast and efficient process; however the quality of weld improves as increase in sheet thickness, increase in operating pressure, increase in weld current and increase in weld time.

- The response of $\mathrm{S} / \mathrm{N}$ ratios with respect to tensile strength to indicate that the significant parameter power and weld time increases whereas, pressure is decreases.

- The contributions of Pressure, Weld time and Power towards tensile strength are $46.46 \%, 9.10 \%$ and $2.93 \%$ respectively as determined by the ANOVA Method.

\section{References}

[1] Dursun Ozyurek "An effect of weld current and weld atmosphere on the resistance spot Weldability of 304L of austenitic stainless steel" Material and design 29 (2008) 597-603, March 2007.

[2] Hessamoddin Moshayedi, Iradj Sattari-far "Numerical and experimental study of nugget size growth in Resistance spot welding of Austenitic stainless steels"
Journal of Material Processing Technology 212 (2012) 347-354, September 2011.

[3] Nachimani Charde, Aravinthan Arumugam "An analysis of spot weld growth on Mild and Stainless Steel with $1 \mathrm{~mm} \& 2 \mathrm{~mm}$ Thicknesses" International Conference on Advanced Science Engineering \& Information Technology, January 2011.

[4] Nachimani Charde "Characterization of Spot Weld Growth on Dissimilar Joints with Different Thicknesses", Journal of Mechanical Engineering \& Sciences, E-ISSN: 2231-8380; Volume 2, June 2012.

[5] R. J. Bowers, C. D. Sorensen and T. W. Eagar "Electrode Geometry in resistance spot welding" American Welding Society \& Welding Research Council, supplement to the welding journal, February 1990.

[6] A. Aravinthan, C. Nachimani "Analysis of Spot weld growth on Mild and Stainless Steel" American Welding Society \& Welding Research Council, supplement to the welding journal, August 2011.

[7] A. K. Pandey, M. I. Khan, K. M. Moeed "Optimization Of Resistance Spot Welding Parameters Using Taguchi Method" Integral University, Lucknow, India. International Journal of Engineering Science and Technology (IJEST), ISSN: 0975-5462 Vol. 5 No.02 February 2013.

[8] B.D.Gurav, S.D.Ambekar "Optimization Of The Welding Parameters In Resistance Spot Welding" International Journal Of Mechanical Engineering And Technology (IJMET), Volume 4, September - October (2013)

[9] Norasiah Muhammad, Yupiter Hp Manurung "Design Parameters Selection and Optimization of Weld Zone Development in Resistance Spot Welding" World Academy of Science, Engineering and Technology 71 2012.

[10] A.G.Thakur, V.M.Nandedkar, "Application of Taguchi Method to determine Resistance Spot Welding Conditions of Austenitic Stainless Steel AISI304", Journal of Scientific and Industrial Research, June 2010.

[11] Taguchi, G. S. Chowdhary (2005) “Taguchi's Quality Engineering Handbook".

[12] "Handbook for Resistance Spot Welding", 2005, Miller Electric Manufacturing Co., Appleton, WI.

[13] O.P.Khanna "A textbook of welding technology", Dhanpat Rai Publication

\section{Author Profile}

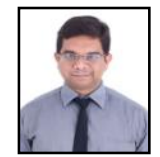

Makwana Brijesh $\mathbf{V}$ received the B.E. degree in Mechanical Engineering from Parul Institute of Engg. And Tech. in 2010 and M.E. in Specialization with CAD-CAM from A. D. Patel Institute of Technology in 2015. During 2011-2012, he works as a lecturer in Diploma College and organized some technical events. He now works with Parul University as an Assistant Professor in Mechanical Engineering Department.

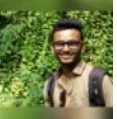

Shah Jay D is currently receiving the B.E degree in Mechanical Engineering from Parul Institute of Engg And Tech. He is a Member of ASME (American Society Of Mechanical Engineers). He is in Core 


\section{International Journal of Science and Research (IJSR) \\ ISSN (Online): 2319-7064}

Index Copernicus Value (2015): 78.96 | Impact Factor (2015): 6.391

Committee of ASME PU Student Chapter. He Also Organized and

Volunteer Various Events for the Student Chapter.

Bhatt Jayant A is currently receiving the B.E degree in Mechanical Engineering from Parul Institute of Engineering And Tech. He Done his Diploma in Mechanical Engineering From Parul Institute of Eng And Tech - Diploma Studies. 